\title{
KONTRAK WARALABA PERSPEKTIF TEORI MULTI AKAD (Analisis Kontrak Waralaba Makanan Seblak Coy di Surakarta)
}

\author{
Devi Nilam Sari
}

\author{
Universitas Islam Negeri Sunan Kalijaga Yogyakarta \\ devidenisa54@gmail.com
}

Received:12-03-2020; Revised:07-06-2020; Accepted: 11-06-2020;

\section{ABSTRACT}

Franchise is an agreement regarding the method of distributing goods or services to consumer. This business must be run according to the procedure and manner specified by the franchisor to the franchisee. Franchise contracts in Indonesia have legal provisions issued by government authorities to bring order to regulate franchise business activities. On the other hand, to protect Indonesian people who are predominantly muslim, it is necessary to study the legal clarity of the franchise business in therm of Islamic law. The focus of the problem in this research is how the franchise contract according to the perspective of multi-contract theory. Seblak Coy is one of the culinary franchise business in Indonesia wich is the object of this research, and uses multi-contract theory as the contract analysis knife. This research is a qualitative descriptive study using secondary data sources such us using books on franchising and research related contract as a theory of analysis and primari sources from direct interviews with Seblak Coy owners. The result showed that the franchise practices carried out by the culinary business of Seblak Coy belong to the multi-contract category, and the elements have been fulfilled because the contract that occur are interdependent with each other, namely the musyarakah, ijarah, ibtikar (copyright). This is known through analysis that shows the fulfillment of multi-contract elements contained in the franchise contract in Seblak Coy.

Keyword: Franchisor, Franchisee, Musyarakah, Ijarah, Ibtikar.

\section{INTISARI}

Waralaba merupakan sebuah perjanjian mengenai metode pendistribusian barang ataupun jasa kepada konsumen. Usaha ini harus dijalankan sesuai prosedur dan cara yang ditetapkan oleh franchisor kepada franchisee. Kontrak Waralaba di Indonesia terdapat ketentuan hukum yang dikeluarkan oleh otoritas pemerintah untuk menertibkan kegiatan bisnis waralaba. Di sisi lain, untuk melindungi masyarakat Indonesia yang mayoritas beragama Islam, perlu dikaji kejelasan hukum dari bisnis waralaba tersebut dipandang dari sudut hukum Islam. Fokus masalah dalam penelitian ini adalah bagaimana kontrak waralaba menurut perspektif teori multi akad. Seblak Coy merupakan salah satu bisnis waralaba kuliner di Indonesia yang menjadi objek penelitian ini, dan menggunakan tori multi akad sebagai pisau analisis kontraknya. Penelitian ini termasuk jenis penelitian deskriptif kualitatif dengan menggunakan sumber data sekunder seperti menggunakan buku-buku mengenai waralaba dan akad-akad terkait penelitian sebagai teori bahan analisis dan sumber primer dari wawancara langsung dengan pemilik Seblak Coy. Hasil penelitian menunjukkan bahwa praktik waralaba yang dilakukan oleh usaha kuliner Seblak Coy termasuk kedalam kategori multi akad, dan telah terpenuhi unsur-unsurnya karena akad yang terjadi saling berketergantungan satu sama lain, yaitu akad musyarakah, akad Ijarah dan Ibtika>r 
(hak cipta). Hal tersebut diketahui melalui analisis yang menunjukkan terpenuhinya unsur-unsur multi akad yang terdapat pada kontrak waralaba di Seblak Coy.

Kata Kunci: Franchisor, Franchisee, Musyarakah, Ijarah, Ibtikar.

\section{A. Pendahuluan}

Sistem ekonomi syariah merupakan suatu perwujudan dari paradigma Islam. Perkembangan sistem ekonomi syariah bukan untuk menyaingi sistem ekonomi kapitalis dan sistem ekonomi sosial, tetapi lebih ditujukan untuk mencari suatu sistem ekonomi yang baik dari sistem ekonomi yang telah ada. Salah satu fenomena yang nyata dari pertumbuhan ekonomi adalah adanya bisnis dengan sistem waralaba (franchise). Waralaba merupakan jenis bisnis yang memiliki perkembangan begitu pesat di dunia perekonomian nasional maupun internasional.

Kehadiran para pihak dalam kontrak merupakan suatu hal yang lazim. Namun yang khas pada perjanjian waralaba adalah yang menjadi objek transaksinya, yaitu Hak Kekayaan Intelektual (HKI), yang berwujud merek dan produk dagang, dan format binis. Waralaba dapat berupa usaha makanan, pakaian dan lain sebagainya. Waralaba makanan merupakan salah satu usaha waralaba yang dapat dikatakan cukup rumit dan harus berhati-hati dalam pengelolaannya, mengingat bahan-bahan baku makanan dan resep bumbu yang dibutuhkan harus berasal dari pihak pemberi waralaba dan pihak mitra dilarang menyiapkan bahan bakunya sendiri, karena dapat mengubah cita rasa kuliner tersebut.

Menurut hukum Islam segala usaha adalah hukum asalnya boleh kecuali ada nash yang melarangnya, sebagaimana dijelaskan juga dalam kaidah fikih ${ }^{1}$ yang menjadi salah satu landasannya. Salah satu parameter untuk menentukan suatu bisnis memenuhi prinsip syariah atau tidak adalah dengan melihat dari akad yang digunakan sebagai landasan operasional suatu bisnis. Perjanjian bisnis di era kontemporer ini jika dilihat sebagian besarnya sangat inovatif dan kreatif, akibat dari persaingan usaha.

Salah satunya dengan cara menggabungkan atau mencampurkan akad satu dengan lainnya dalam satu kontrak kesepakatan yang dilakukan antara dua pihak. Sebagai contoh, dalam transaksi obligasi syariah mengandung sedikitnya akad mudarabah, ijarah dan wakalah. Dalam setiap transaksi, akad-akad tersebut dilakukan dengan cara bersamaan dan atau terdapat akad yang tidak bisa untuk digabungan ataupun ditinggalkan, karena akad-akad tersebut memiliki keterkaitan. ${ }^{2}$ Transaksi seperti itulah yang dalam penelitian ini diistilahkan dengan "multi akad" atau dapat disebut dengan al-'uqud al-murakkabah.

Multi dalam Kamus Besar Bahasa Indonesi adalah banyak (bermacam-macam). ${ }^{3}$ Sedangkan akad adalah hubungan antara dua pernyataan yang menimbulkan hukum syar'i berupa kewajiban yang harus dilaksanakan oleh salah satu pihak atau keduanya. ${ }^{4}$ Dalam kajian fikih, istilah multi akad dikenal dengan al-'uqud al-murakkabah, dalam bahasa inggris diseut hybrid contract yaitu suatu kontrak yang menghimpun beberapa akad dalam suatu kontrak. ${ }^{5}$ Multi akad merupakan kumpulan beberapa akad yang di desain menjadi satu paket akad yang

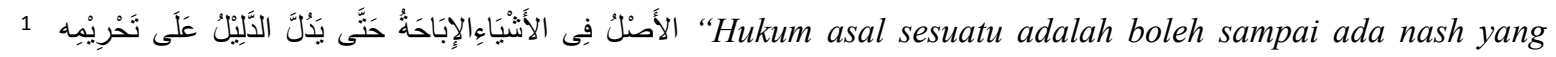
melarangnya”. Lihat Jaih Mubarok, Sejarah dan Kaidah Asasi (Jakarta: Raja Grafindo Persada, 2002), 135.

${ }^{2}$ Hasanudin Maulana, "Multiakad Dalam Transaksi Syariah Kontemporer Pada Lembaga Keuangan Syariah Di Indonesia," Al-Iqtishad: Journal of Islamic Economics 3, no. 1 (2016), 156.

${ }^{3}$ Kamus Besar Bahasa Indonesia, https://kbbi.web.id/multi, diakses pada 8 Januari 2020.

${ }^{4}$ Muhammad Abu Zahrah, al-Milkiyyah wa Nazariyyatu al- 'Aqd (Kairo: Dar al-Fikr al-Arabi, 1996), h. 173.

${ }^{5}$ Harun, "Multi Akad Dalam Tataran Fiqh,” Jurnal Suhuf, Vol. 30, No. 2 (2018), 179. 
memiliki tahapan-tahapan dan bagian-bagian akad. Multi akad sebagai suatu sarana untuk memenuhi kebutuhan bisnis, serta sangat berperan untuk mempermudah dan meminimalisir risiko. Transaksi multi akad juga merupakan akad-akad kontemporer yang belum ada dan belum dijelaskan dalam kitab-kitab turats. ${ }^{6}$

Oleh sebab demikian, multi akad masih menjadi polemik yang diperdebatkan di kalangan ulama fikih. Sejumlah hadis Nabi yang secara lahiriah menunjukkan larangan penggunaan multi $\mathrm{akad}^{7}$ sebagai salah satu sebabnya. Seperti penggabungan jual beli dan pinjaman, dilarang untuk digabung karena dapat menimbulkan ketidakjelasan dan memiliki unsur riba. Para ulama menjelaskan bahwa yang dilarang adalah jika akad qard menjadi akad inti dan menjadi hajat utama pelaku akad, sedangkan bai' menjadi akad pelengkap. Akad-akad lain seperti ijarah juga tidak boleh digabungkan jika digabung dengan akad qardu selama akad qardu menjadi akad inti. ${ }^{8}$

Terjadinya multi akad dalam transaksi bisa terjadi secara alamiah yang terjadi antara akad pokok (al- 'aqd al-asli) dan akad yang mengikutinya (al-'aqd al-tabi'i), seperti akad qard yang kemudian diikuti oleh akad rahn dalam transaksi pijam meminjam di Bank atau Pegadaian ataupun terjadi karena adanya modifikasi terhadap akad. ${ }^{9}$ Selain transaksi yang dipraktikkan di lembaga keuangan, multi akad juga tentunya telah di praktikkan pada konsep bisnis lainnya yang dilakukan oleh beberapa pihak yang terlibat di dalamnya, salah satunya adalah bisnis dengan konsep waralaba. Bisnis waralaba hakikatnya telah lama dikenal dalam ekonomi Islam dengan nama syirkah atau musyarakah ${ }^{10}$ (kerjasama) untuk memperoleh keuntungan pada waktu tertentu sesuai perjanjian. ${ }^{11}$ Kemudian aspek ijarah $^{12}$ terletak pada adanya akad sewa menyewa antara franchisor dan franchisee atas hak kekayaan intelektual berupa merek dan hak cipta yang memberikan manfaat ekonomi kepada pemiliknya. ${ }^{13}$

${ }^{6}$ Oni Sahroni dan M. Hasanuddin, Fikih Muamalah: Dinamika Teori Akad dan Implementasinya Dalam Ekonomi Syariah, (Jakarta: Raja Grafindo Persada, 2016), 201.

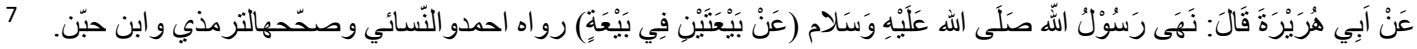

Dari abi hurairah, ia berkata: Rasulullah saw. Melarang dua jual beli di dalam satu jual beli (diriwayatkan-dia oleh Ahmad dan Nasa'i dan dishahkan-dia oleh Tirmidzi dan Ibnu Hibban).

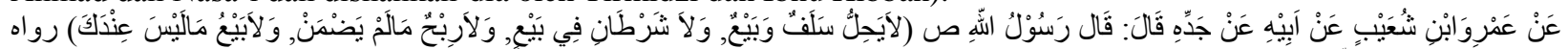

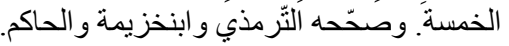

Dari 'Amr bin Syuaib, dari bapaknya, dari datuknya, ia berkata: telah bersabda rasulullah saw: tidak halal pinjaman dan jual, dan tidak halal dua syarat dan satu penjualan dan tidak halal keuntungan dari barang yang ia tidak tanggung, dan tidak halal menjual barang yang tidak ada padamu. (diriwayatkan dia oleh lima dan disahkan oleh Tirmidzi dan Ibnu Khuzaimah dan Hakim). Lihat dalam Ibnu Hajar al'Asqalani, Bulughul Maram, terj. A. Hasan, (bandung: CV Penerbit Diponegoro, 2006), 350.

${ }^{8}$ Oni Sahroni dan M. Hasanuddin, Fikih Muamalah: Dinamika Teori Akad dan Implementasinya Dalam Ekonomi Syariah, ..., 205.

${ }^{9}$ Harun, "Multi Akad Dalam Tataran Fiqh", ..., 181.

${ }^{10}$ Syirkah atau musyarakah berarti akad kerja sama antara dua pihak atau lebih untuk suatu usaha tertentu dimana masing-masing pihak memberi kontribusi dana atau, dengan kesepakatan bahwa resiko dan keuntungan akan ditanggung bersama sesuai kesepakatan. Muhammad Ridwan, Konstruksi Bank Syariah Indonesia (Yogyakarta: Pustaka SM, 2007), 39.

${ }^{11}$ Inas Fahmiyah dan Moh. Idil Ghufron, "Konsep Waralaba Perspektif Ekonomi Islam ", Jurnal Amwaluna, Vol. 3, No. 1 (2019), 143.

12 Ijarah adalah akad pemindahan hak guna atas barang atau jasa, melalui pembayaran upah sewa, tanpa diikuti dengan pemindahan kepemilikan atas barang itu sendiri. Muhammad Syafi'i Antonio, Bank Syariah Dari Teori Ke Praktik (Jakarta: Gema Insani, 2001), 117.

${ }^{13}$ Norman Syahdar Idrus, "Aspek Hukum Perjanjian Waralaba (Franchise) Dalam Perspektif Hukum Perdata Dan Hukum Islam,” Jurnal Yuridis Vol. 4, No. 1 (2017), 28. 
Salah satu waralaba makanan lokal Indonesia adalah waralaba makanan Seblak Coy. Dalam kontrak waralaba ini terdapat penggabungan akad di dalamnya sehingga dapat dikatakan sebagai multi akad, diantaranya yaitu akad musyarakah dan akad ijarah, selain itu juga ada hak ibtikar yang harus dilindungi. Sekilas mengenai berdirinya seblak coy yang dirintis oleh kang Imo $^{14}$ sejak tahun 2014 di kota Solo, dalam pengelolaan bisnisnnya menerapkan kontrak kemitraan dengan konsep waralaba (franchise), dan telah memiliki beberapa gerai di Indonesia. Dalam penawaran kemitraannya, waralaba kuliner Seblak Coy bersifat fleksibel dalam jangka waktu masa kemitraan selama 5 tahun, kemudian diperbaharui pada setiap tahun dan memberi harga yang sangat terjangkau sesuai dengan kebutuhan usaha.

Menariknya, usaha kuliner Seblak Coy ini dirintis dan didirikan di kota Solo yang bersuku jawa dan belum mengenal kuliner seblak khas bandung, serta dalam pamflet pemasarannya terdapat slogan "menggoyang lidah tapi non MSG", ini menyatakan bahwa produk seblak yang ada di Seblak Coy tidak mengandung MSG (mononatrium glutamate) ${ }^{15}$ dalam penyajiannya. ${ }^{16}$ Dari berbagai penawaran, keuntungan dan rendahnya resiko pada bisnis waralaba, serta masih langkanya kuliner seblak di daerah yang bersuku jawa, akhirnya memikat para masyarakat untuk melakukan bisnis dengan kontrak Waralaba (Franchise) yang kemudian menyebabkan banyak cabang waralaba makanan pada usaha kuliner Seblak Coy di seluruh Indonesia. Kemudian dalam kontraknya terdapat sistem bagi hasil keuntungan bersih di setiap bulan. ${ }^{17}$

Maraknya bisnis waralaba, disebabkan sistem tersebut lebih menguntungkan. Bagi franchisor (pemberi waralaba) merupakan cara yang cepat untuk memperluas sistem distribusi dengan modal minimum, kemampuan untuk berkembang tanpa biaya pengembangan dan menerima hasil dari franchisee (penerima waralaba). ${ }^{18}$ Kontrak Waralaba di Indonesia terdapat peraturan yang dikeluarkan oleh otoritas pemerintah untuk menertibkan kegiatannya, yakni dalam Peraturan Pemerintah No. 42 Tahun 2007 tentang Waralaba, sedangkan waralaba makanan diatur dalam Peraturan Menteri Perdagangan Nomor 58/M-Dag/Per/9/2014 tentang Perubahan atas Peraturan Menteri Perdagangan Nomor 07/M-Dag/Per/2013 tentang Pengembangan Kemitraan Dalam Waralaba Untuk Jenis Usaha Jasa Makanan Dan Minuman. ${ }^{19}$

Di sisi lain, untuk melindungi masyarakat Indonesia yang mayoritas beragama Islam, perlu dikaji kejelasan hukum dari bisnis waralaba tersebut dipandang dari sudut hukum Islam khususnya menurut perspektif teori multi akad, yaitu penggabungan beberapa akad yang terdapat dalam kontrak waralaba, adapun akad-akad tersebut terdiri dari akad musyarakah (kerja sama), ijarah (sewa) dan adanya hak ibtikar (hak cipta) yang berbentuk lisensi atas merek usaha yang harus digunakan dengan semestinya oleh pihak yang diberi hak tersebut karena hak cipta telah dilindungi oleh negara.

\footnotetext{
${ }^{14}$ Achmad Maulidiansyah kerap disapa Kang Imo, Pemilik Waralaba Makanan "Seblak Coy”.

${ }^{15}$ MSG adalah molekul sodium yang dikombinasi dengan asam glutamate. Molekul sodium digunakan untuk menstabilkan molekul glutamate berfungsi sebagai penyedap rasa. Sebagian ilmuwan menyebutkan glutamate sebagai "umami", sebuah penyebutan untuk rasa kelima yang dapat dirasakan oleh indera perasa manusia, selain manis, asin, pahit dan asam. https://www.alodokter.com/kontroversi-umami-dari-msg, diakses pada 9 Agustus 2020.

${ }^{16}$ Achmad Maulidiansyah, Pemilik Seblak Coy, Wawancara Pribadi, 21 November 2019, jam 10.00 WIB.

${ }^{17} \mathrm{Ibid}$.

${ }^{18}$ Norman Syahdar Idrus, "Aspek Hukum Perjanjian Waralaba (Franchise) Dalam Perspektif Hukum Perdata Dan Hukum Islam", ..., 29.

${ }^{19}$ Zil Aidi and Hasna Farida, "Perlindungan Hukum Para Pihak Dalam Perjanjian Waralaba Makanan," JCH (Jurnal Cendekia Hukum) Vol. 4, No. 2 (2019), 211.
} 
Berangkat dari uraian yang telah dikemukakan di atas mengenai kontrak waralaba makanan Seblak Coy di Surakarta yang pengaplikasian kontrak perjanjiannya dengan franchisee mengandung unsur multi akad, melatarbelakangi penulis untuk mengangkat permasalahan tersebut sebagai bahan penyusunan studi kasus yang selanjutnya akan dianalisis mengenai implementasi multi akad yang terkandung dalam praktek bisnis waralaba serta kesesuaiannya dengan multi akad yang diperbolehkan menurut syariah.

\section{B. Metode Penelitian}

Jenis penelitian adalah penelitian lapangan (field research) bersifat deskriptif kualitatif karena data hasil penelitian lebih berkenaan dengan interpretasi terhadap data yang ditemukan di lapangan. ${ }^{20}$ Objek penelitian yaitu sistematika dan pelaksanaan kontrak waralaba seblak coy yang berlokasi di Surakarta. Pada penelitian ini, peneliti terjun ke lapangan, mempelajari suatu proses atau penemuan yang terjadi secara alami, mencatat data yang di peroleh secara langsung melalui fakta yang terjadi, keadaan dan dari sumber-sumber yang memiliki keterkaitan dengan usaha kuliner seblak coy serta perjanjian untuk menjadi mitra waralaba, melakukan wawancara kepada franchisor selanjutnya menganalisis secara deskriptif dengan jenis penelitian kualitatif.

Pengumpulan data dengan cara mengumpulkan data primer dan sekunder. Data sekunder yang meliputi buku-buku, pendapat para ahli hukum dan seluruh laporan dari hasil penelitian. Adapun data yang diperlukan adalah, teori multi akad melalui buku-buku, jurnal dan karya tulis ilmiah yang mengkaji tentang multi akad. Metode Pengumpulan Data dengan cara wawancara, observasi dan dokumentasi. Pada penelitian ini wawancara diajukan kepada pemilik waralaba. Wawancara informasi mengenai sejarah berdirinya dan perkembangan waralaba pada waralaba makanan seblak coy. Selanjutnya dilakukan pengamatan (observasi) secara langsung pada outlet seblak coy dengan melihat dan mengamati bagaimana keadaan outlet seblak coy, serta didukung dengan dokumentasi. Dari hasil pengumpulan data, selanjutnya dianalisis secara induktif deduktif, dengan melakukan penalaran dari hal yang bersifat umum ke hal-hal yang bersifat khusus.

\section{Hasil dan Pembahasan}

\section{Konsep Bisnis Waralaba Pada Kontrak Waralaba Seblak Coy}

Waralaba (franchise) adalah sebuah perjanjian di mana seseorang dengan ide bagus untuk bisnis menjual hak dengan menggunakan nama bisnis tersebut dan untuk menjual produk atau jasa kepada orang lain dalam sebuah teritorial tertentu, sehingga waralaba harus dijalankan sesuai pewaralaba. ${ }^{21}$ Franchisor (pewaralaba) memberikan lisensi menggunakan suatu Hak Kekayaan Intelektual seperti Hak Cipta, Merek, Paten, Rahasia Dagang kepada franchisee (terwaralaba), atas dasar lisensi itu franchisee berkewajiban untuk membayar royalty fee. ${ }^{22}$

Waralaba dapat dibedakan menjadi dua bentuk, pertama waralaba merek dagang dilakukan dengan cara franchisor memberikan hak kepada franchisee untuk melakukan penjualan produk yang telah dikembangkan oleh franchisor beserta pemberian lisensi untuk menggunakan merek dagang. Dari pemberian hak tersebut franchisor berhak mendapatkan imbalan berupa royalty dari keuntungan dari penjualan produknya. Kedua, waralaba format bisnis, dilakukan dengan memberikan lisensi dan hak-hak kepada pihak lain untuk melakukan suatu usaha dengan

\footnotetext{
${ }^{20}$ Sugiyono, Metode Penelitian Kuantitatif Kualitatif dan R \& D, (Bandung: Alfabeta, 2014), 8.

${ }^{21}$ William G. Nickels, dkk, Pengantar Bisnis, (Jakarta: Salemba Empat, 2009), 174.

${ }^{22}$ Lukman Santoso, "Urgensi Tanda Tangan dan Materai Dalam Memberikan Kepastian Hukum Terhadap Kontrak Waralaba (franchise)", Syariah: Jurnal Hukum dan Pemikiran, Vol. 16, No. 2, (2016), 116.
} 
menggunakan merek dagang atau nama dagang franchisor, dan untuk menggunakan keseluruhan paket yang terdiri dari seluruh elemen yang diperlukan dengan tujuan melatih franchisee menjadi terampil dalam bisnis dan untuk menjalankannya mendapat bantuan secara terus-menerus atas dasar ketentuan yang telah ditentukan sebelumnya. ${ }^{23}$

Selain itu terdapat hak dan kewajiban yang harus terpenuhi, yakni: ${ }^{24}$

a. Kewajiban franchisor yang menjadi hak franchisee adalah sebagai berikut:

1) Brand name yang meliputi logo, peralatan dan lain-lain.

2) Sistem operasional bisnis.

3) Dukungan dan pengawasan (monitoring) yang bertujuan untuk memastikan bahwa sistem yang disediakan dijalankan dengan baik dan benar secara konsisten.

4) Penggabungan promosi (joint promotion).

5) Pemasokan yang berlaku bagi franchisee tertentu, misalnya bagi franchisor yang merupakan supplier bahan makanan/minuman.

b. Kewajiban franchise yang merupakan hak franchisor dapat dibedakan menjadi dua macam:

1) Kompensasi langsung dalam bentuk nilai moneter (direct monetary compensation), dapat diwujudkan ke dalam dua bentuk yaitu Lump sum payment adalah suatu jumlah uang yang telah dihitung terlebih dahulu yang wajib dibayarkan oleh franchisee pada saat persetujuan pemberian waralaba disepakati, dan royalty yang merupakan sejumlah pembayaran terhadap suatu presentasi tertentu yang dihitung dari jumlah produksi dan/atau penjualan barang dan/atau jasa yang diproduksi atau dijual.

2) Kompensasi tidak langsung dalam bentuk nilai moneter (indirect and nonmonetary compensation), meliputi keuntungan dari penjualan barang yang merupakan satu paket dengan pemberian waralaba, pembayaran kompensasi juga dapat diwujudkan dalam bentuk pembagian dividen dalam bentuk pinjaman jangka pendek maupun jangka panjang, cost shifting atau pengalihan atas sebagian biaya yang harus dikeluarkan oleh Franchisor dalam rangka mencegah terjadinya pelanggaran atau sebagai upaya perlindungan hak atas kekayaan intelektual.

Beberapa hal yang biasanya dimuat di dalam perjanjian waralaba, yaitu: ${ }^{25}$

a. Nama, alamat dan tempat kedudukan perusahaan masing-masing pihak

b. Nama dan jabatan masing-masing pihak yang berwenang menandatangani perjanjian

c. Nama dan jenis HKI, penemuan atau ciri khas usaha misalnya manajemen, cara penjalan atau cara distribusi yang merupakan karakteristik khusus yang menjadi obyek waralaba

d. Hak dan kewajiban masing-masing pihak serta fisilitas yang diberikan kepada franchisee

e. Wilayah pemasaran

f. Jangka waktu, tata cara perpanjangan sera syarat-syarat perpanjangan perjanjian

g. Cara penyelesaian perselisihan

h. Tata cara pembayaraan imbalan.

Salah satu bisnis waralaba yang ada di Indonesia adalah seblak coy. Seblak merupakan salah satu kuliner khas Bandung. Hingga saat ini seblak Bandung makin meningkat eksistensinya dikalangan anak muda. Bahkan di luar kota Bandung, seblak telah menjadi salah satu kuliner

${ }^{23}$ Linda Firdawati, "Perjanjian Waralaba Menurut Hukum Islam,” Jurnal Asas, Vol.3, No.1 (2011), 42.

${ }^{24}$ Burhanuddin, Hukum Kontrak Syariah, (Yogyakarta: BPFE, 2009), 244.

${ }^{25}$ Arus Akbar Silondae, dan Andi Fariana, Aspek Hukum dalam Ekonomi dan Bisnis, (Jakarta: Mitra Wacana Media, 2013), 33. 
lokal yang dijadikan sebagai bisnis dibidang usah. Seblak coy adalah salah satu bisnis kuliner khas Bandung yang berdiri di Solo pada tahun 2014, didirikan oleh Achmad Maulidiansyah, S.Sn, yang kerap disapa kang Imo. Pada awal memulai bisnisnya, kang Imo membuka usaha kuliner seblak yang pertama berletak di daerah Technopark, Kecamatan Jebres, Surakarta. Kang Imo sendiri yang mengelola usahanya sampai memasak dan menjual seblak tersebut.

Seiring berjalan waktu usahanya semakin berkembang yang mengharuskan kang Imo untuk mencari karyawan untuk membantunya dalam operasional usahanya di bidang memasak dan pelayanan konsumen. Setelah dirasakan perkembangan bisnis seblaknya, kang Imo melakukan pelegalan nama menjadi "Seblak Coy Ala Kang Imo" dan dicatatkan dibawah naungan notaris. Karena semakin berkembangnya dunia bisnis dan telah merambah hingga Indonesia yang salah satunya bisnis dengan sistem waralaba (franchise), pada tahun 2016 kang Imo melakukan penguatan hukum atas bisnisnya agar dapat lebih berkembang dan maju dengan cara mendaftarkan Seblak Coy menjadi bisnis waralaba (franchise).

Usaha kuliner khas bandung yang kang Imo tekuni kini mengalami perkembangan yang baik setelah melekatnya status franchise pada Seblak Coy, juga diikuti beberapa pengusaha yang mengajukan dirinya menjadi mitra franchise untuk bergabung dalam usaha kulinernya. Seblak coy telah memiliki beberapa gerai yang terletak di delapan kota besar, yaitu Solo, Wonogiri, Yogyakarta, Purbalingga, Bandung, Bekasi, Depok dan Berau Kalimantan Selatan. ${ }^{26}$ Kontrak perjanjian waralaba pada Seblak Coy selama 5 tahun dan dapat diperpanjang. Dalam jangka 5 tahun ini, selalu dilakukan pembaharuan kontrak di setiap satu tahun sekali. Pembaharuan kontrak ini bertujuan agar menyamaratakan perkembangan usaha, seperti penambahan ataupun perubahan menu, bahan baku atau bumbu-bumbu, dan perubahan manajemen pengelolaan. Untuk bergabung menjadi mitra waralaba Seblak Coy ala Kang Imo, calon mitra harus melakukan prosedur sebagai berikut:

a. Calon franchisee harus menyiapkan lokasi, yang akan disurvey langsung oleh pihak franchisor atau seblak coy dengan memperhatikan lokasi strategis, konsumtif, dan prospektif.

b. Setelah sepakat mengenai lokasi, selanjutnya melakukan kesepakatan MoU (Memorandum of Understanding) antara kedua belah pihak dan penandatanganan kontrak.

c. Franchisee melakukan pembayaran seharga Rp.20.000.000,- kepada franchisor yang dapat disebut sebagai initial fee atau pembayaran diawal akad sebagai imbalan atas fasilitas yang akan didapat oleh franchisee seperti dana untuk peralatan memasak, pelatihan-pelatihan, dan fasilitas lain yang diberikan oleh pihak Seblak Coy kepada mitra, serta hak atas merek.

d. Selanjutnya serah terima objek waralaba kepada franchisee, yang akan dikelola oleh franchisee atas pengawasan franchisor.

Adapun fasilitas yang didapat franchisee adalah:

a. Stok bahan diberikan secara gratis selama 3 minggu dimulai sejak pembukaan outlet

b. Pelatihan karyawan sampai mandiri

c. Quality control selama satu tahun kedepan

d. Pelatihan franchisee dalam hal managemen pengelolaan, strategi pemasaran, pemahaman SOP, analisis HPP, target BEP, pengaturan SDM. Dan pelatihan kepada karyawan dalam hal memasak, bahan apa yang harus digunakan, dan pelayanan konsumen.

e. Booth dan seperangkat alat masak

f. Branding mencakup desain tempat

${ }^{26}$ Achmad Maulidiansyah, Pemilik Seblak Coy, Wawancara Pribadi, 21 November 2019.

[85] 
g. Seragam 2 set: kaos chef, celemek, topi chef, pin logo seblak coy

h. Bahan packing selama 3 minggu.

i. Fasilitasi pertemuan untuk mendiskusikan kemajuan usaha setiap satu bulan sekali.

Dalam bisnis dengan konsep waralaba, para pihak yang melakukan perjanjian dengan pihak pemilik seblak coy harus memenuhi hak dan kewajiban yang melekat dan tertera dalam isi kontrak, yakni:

a. Hak dan kewajiban pihak I sebagai pemilik merek dan resep seblak coy:

1) Berkewajiban menyediakan fasilitas atau properti usaha pada unit usaha pihak II Seblak Coy;

2) Berkewajiban memberikan pelatihan untuk karyawan baru Seblak Coy;

3) Berkewajiban memberikan pasokan bahan dasar dan bumbu resep asli Seblak Coy dengan estimasi stok untuk 3 minggu;

4) Berkewajiban meningkatkan kualitas cheff pada unit usaha penerima waralaba Seblak Coy;

5) Berkewajiban sebagai quality control produk atau menu dalam unit usaha penerima waralaba Seblak Coy;

6) Berkewajiban sebagai quality control atas bahan baku menu yang dijual pada unit usaha peneria waralaba Seblak Coy sesuai dengan standar operting dan prosedur perusahaan Seblak Coy;

7) Berkewajiban mengadakan pelatihan untuk meningkatkan kapasitas karyawan, menyelenggarakan riset dan pengembangan usaha, menjalankan misi marketing dan perluasan usaha,

8) Memberikan seragam karyawan

9) Berhak atas sharing provit

b. Hak dan kewajiban pihak II sebagai penerima merek dan resep seblak coy:

1) Berkewajiban membeli bahan dasar dan bumbu asli resep Seblak Coy kepada pihak I

2) Berkewajiban Menjalankan fungsi manajemen usaha Seblak Coy menuju tingkat provit usaha yang semakin tinggi;

3) Berkewajiban menjalankan asas usaha Seblak Coy dengan berpedoman pada prinsip efektif dan efisien

4) Membiayai pengadaan bahan baku usaha, membayar gaji karyawan, membayar sewa lapak atau kios Seblak Coy, membayar Tunjangan Hari Raya, membayar tunjangan kesehatan, membiayai perawatan properti usaha, mengalokasikan sharing provit kepada pihak I, mengalokasikan sharing provit untuk pengembangan usaha, mengalokasikan sharing provit untuk biaya manajemen dan mengalokasikan sharing provit untuk saving perusahaan;

5) Berhak menerima langsung dan mengelola arus kas usaha untuk kemudian dialokasikan sesuai dengan peruntukannya berdasarkan asas profesional dan transparan.

6) Berhak atas sharing provit

Mengenai pembagian keuntungan hasil usaha, dalam isi kontrak waralaba seblak coy menentukan bahwa petentuan alokasi omzet harian akan dihitung per-30 hari dengan pembagian:

a. Biaya tetap dan biaya tidak tetap tiap unit usaha mencakup biaya operasional dan bahan jual sebesar $40 \%$ dari target omzet harian

b. Gaji cheff dan helper adalah sebesar $10 \%$ dari omzet harian 
c. Sharing provit sebesar 50\% dari pendapatan bersih harian. Yang dimaksud dengan sharing provit adalah pengalokasian pendapatan bersih harian setelah dikurangi biaya tetap dan biaya tidak tetap beserta biaya produksi dan gaji karyawan. Dengan pembagian sebagai berikut:

1) Alokasi Pihak I sebesar 10\%;

2) Alokasi Pihak II sebesar 15\%;

3) Alokasi sharing provit untuk biaya manajemen dan operasi sebesar $10 \%$

4) Alokasi untuk saving perusahaan sebesar 5\%

5) Alokasi untuk maintenance alat sebesar 5\%

6) Alokasi untuk insentif unit berupa: THR, Tunjangan Kesehatan, liburan karyawan dan Peningkatan kapasitas sebesar 5\%. ${ }^{27}$

\section{Kontrak Waralaba di Seblak Coy Perspektif Multi Akad}

Menurut bahasa, akad adalah as-syad dan ar-rabt (ikatan dan mengikat). Dalam istilah para ulama fikih, akad adalah mengikatkan antara dua ucapan atau perbuatan yang dilakukan dua belah pihak sehingga menimbulkan pengaruh yang sah. Maksud dari dua ucapan dan perbuatan yang dilakukan kedua belah pihak adalah ijab dan Kabul yang menimbulkan akibat pada objek perikatan. ${ }^{28}$ Kontrak atau perjanjian dalam hukum perdata islam disebut dengan akad. Secara terminologi adalah perikatan atau perserikatan antara ijab dan kabul sesuai dengan kehendak syariah (Allah dan Rasul-Nya) yang menimbulkan akibat hukum pada obyek perikatan. ${ }^{29}$

Sedangkan multi akad adalah kesepakatan dua pihak untuk melaksanakan suatu transaksi yang meliputi dua akad atau lebih, kemudian dari transaksi itu mengakibatkan timbulnya akibat hukum yang satu pula, karena diantara akad yang digabungkan memiliki satu keterkaitan yang tidak dapat dipisahkan. ${ }^{30}$ Multi akad merupakan kumpulan beberapa akad yang di desain menjadi satu paket akad dan memiliki tahapan-tahapan akad. Multi akad itu dibuat karena untuk memenuhi kebutuhan pasar, industri dan nasabah, misalnya meminimalisir risiko, memperbesar keuntungan dan lain-lain. Transaksi multi akad juga merupakan akad-akad kontemporer yang belum ada dan belum dijelaskan dalam kitab-kitab turats. ${ }^{31}$

Transaksi multi akad diperbolehkan karena merupakan salah satu bentuk aktifitas muamalah yang dapat membantu meringankan salah satu pihak atau saling menguntungkan, sebagaimana dalam kaidah fikih:

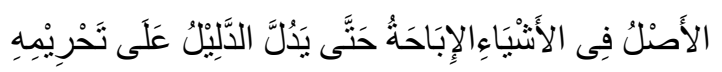

Artinya : "Hukum asal sesuatu adalah boleh sampai ada nash yang melarangnya". 32

Transaksi multi akad akad dapat dinyatakan sah dengan syarat telah memenuhi rukun dan syarat pada setiap akad yang membentuknya. ${ }^{33}$ Pada hakikatnya multi akad memiliki karakteristik tersendiri, yakni pelaku akadnya adalah sama, objek akadnya adalah sama,

${ }^{27}$ Achmad Maulidiansyah, Pemilik Seblak Coy, Wawancara Pribadi, 21 November 2019.

${ }^{28}$ Abdul Karim Zaidani, al-Mudkhal al-Syariah al-Islamiyyah, (Beirut: Muassasah al-Risalah, 1996), 239.

${ }^{29}$ Oni Sahroni dan M. Hasanuddin, Fikih Muamalah: Dinamika Teori Akad dan Implementasinya Dalam Ekonomi Syariah, ..., 5.

${ }^{30}$ Yosi Aryanti, "Multi Akad (Al-Uqud Al-Murakkabah) Di Perbankan Syariah Perspektif Fiqh Muamalah," JURIS (Jurnal Ilmiah Syariah), Vol. 15, No. 2 (2017), 177.

${ }^{31}$ Oni Sahroni dan M. Hasanuddin, Fikih Muamalah: Dinamika Teori Akad dan Implementasinya Dalam Ekonomi Syariah, ..., 201.

32 Jaih Mubarok, Sejarah dan Kaidah Asasi, ..., 135.

${ }^{33}$ Burhanuddin Susamto, "Tingkat Penggunaan Multi Akad Dalam Fatwa Dewan Syari'Ah Nasional-Majelis Ulama Indonesia (DSN-MUI),” Al-Ihkam: Jurnal Hukum \& Pranata Sosial, Vol. 11, No. 1 (2016), 207. 
pengaruh akadnya adalah sama, pengaruh dari satu akad, ada ta'alluq (saling memahami) antara dua akad tersebut. ${ }^{34}$

Kriteria multi akad yang diperbolehkan dalam Islam: ${ }^{35}$

a. Tidak termasuk akad yang dilarang dalam nash untuk digabungkan, seperti menggabungkan jual beli dan pinjaman.

b. Tidak termasuk dalam hilal ribawiyah, yaitu mengubah hukum menjadi hukum baru dengan cara yang tidak dibenarkan, seperti bai' al- 'inah yang mendapatkan bunga atas pinjaman dengan modus jual beli.

c. Tidak boleh menyebabkan riba, seperti menggabungkan qard dengan mua'awadah

d. Bukan termasuk hukumnya berentengan. Seperti antara hibah dan jual beli.

Multi akad dapat terjadi secara alamiyah karena memiliki sifat yang saling berhubungan. Artinya akad yang bersifat mengikuti (al-'aqd al-tabi'i) hanya bisa berlaku apabila akad pokoknya (al- 'aqd al-asli) berlaku. Misalnya, jika akad yang diikuti tabarru', maka akad yang mengikuti juga tabarru'. Kemudian, jika akad yang diikuti batal, maka akad yang mengikuti. Selain itu multi akad juga dapat terjadi akibat dari hasil modifikasi (al-'uqud al-murakkabah alta'dilah) tersusun atas akad-akad yang berlakunya bersifat mandiri tanpa tergantung dengan akad lainnya. Akad ini memiliki tujuan untuk memudahkan penerapan akad itu pada transaksi syariah. ${ }^{36}$ Disamping hal tersebut, multi akad juga memiliki dua ragam dalam implementasinya pada transaksi syariah, yakni: ${ }^{37}$

a. Multi akad yang menggunakan rangkaian berurutan (akad pertama diikuti dengan akad kedua dan seterusnya). Contoh akad mudarabah yang disertai dengan wakalah.

b. Multi akad yang tidak menggunakan rangkaian berurutan (akad pertama dilengkapi dengan akad kedua dan seterusnya). Dalam bentuk ini, pemenuhan rukun dan syarat yang terkandung dalam setiap akad tidak harus dilakukan secara formal dan tertib, bahkan dapat digabung dengan ketentuan tidak ada syarat-syarat yang menimbulkan batalnya akad satu karena akad lainnya. Contohnya, akad dalam produk kartu kredit syariah dengan menggunakan akad ijarah, kafalah dan qard yang dilakukan dengan satu akad saja.

Tanpa kita sadari bahwa multi akad telah banyak diterapkan dalam dunia usaha, salah satunya adalah pada usaha kuliner Seblak Coy yang menerapkan sistem waralaba. Dari sistem bisnis tersebut, terjalinlah sebuah mitra antara franchisee yaitu pihak yang mengajukan dengan franchisor (Seblak Coy). Tidak hanya menjadi mitra, penerima waralaba juga mendapatkan hak sewa atas merek dan manajemen pengelolaan serta quality control dari pihak franchisor (seblak coy). Dalam penggunaan hak merek tersebut pihak penerima waralaba harus mengikuti ketentuan dari pihak franchisor, sebagaimana tercantum pada MoU (Memorandum of Understanding) yang telah disepakati di awal perjanjian. Dari hal tersebut terjadi suatu akad kerjasama, dalam hukum Islam disebut sebagai akad musyarakah. Selain akad tersebut, juga telah terjadi akad sewa merek usaha yang dalam hukum Islam disebut akad ijarah, sebab merek usaha yang digunakan penerima waralaba adalah Hak Kekayaan Intelektual (HKI) milik

34 Oni Sahroni dan M. Hasanuddin, Fikih Muamalah: Dinamika Teori Akad dan Implementasinya Dalam Ekonomi Syariah, ..., 201.

35 Ibid., 208.

${ }^{36}$ Burhanuddin Susamto, "Tingkat Penggunaan Multi Akad Dalam Fatwa Dewan Syari'Ah Nasional-Majelis Ulama Indonesia (DSN-MUI),” ..., 201.

${ }^{37}$ Oni Sahroni dan M. Hasanuddin, Fikih Muamalah: Dinamika Teori Akad dan Implementasinya Dalam Ekonomi Syariah, ..., 209. 
franchisor dan telah dipatenkan untuk dilindungi oleh negara. Serta perlindungan nama baik perusahaan atau hak cipta (ibtikar)atas merek harus dijaga dengan baik dalam waktu tertentu oleh penerima waralaba dengan mengikuti ketentuan dan prosedur yang telah disepakati.

Oleh karena itu agama menghendaki agar pelaksanaan multi akad pada kontrak waralaba itu senantiasa diperhatikan ketentuan-ketentuan yang bisa menjamin dalam pelaksanaannya dan tidak merugikan salah satu pihak serta terpelihara pula maksud-maksud mulia yang di inginkan agama. Dalam hal multi akad dibolehkan karena akad ada untuk memperjelas hak dan kewajiban pihak akad, maka setiap akad baru memperjelas hak dan kewajiban pihak akad itu diperbolehkan. ${ }^{38}$ Sebelum menentukan transaksi multi akad yang dipraktikkan pada kontrakk waralaba makanan seblak coy, harus diketahui terlebih dahulu mengenai keabsahan setiap akad yang terbentuk sebagai fondasi kontrak waralaba, akibat dari penggabungan beberapa akad, yakni musyarakah, ijarah dan adanya hak cipta (ibtikar) yang harus terpenuhi segala prestasi yang terkandung di dalamnya.

Musyarakah adalah akad yang dilakukan oleh orang yang mengikatkan diri untuk bekerjasama, dimana masing-masing pihak mempunyai hak untuk melakukan tindakan hukum terhadap modal yang dikelola. ${ }^{39}$ Sedangkan al-musyarakat merupakan kata jamak dari musyarakah, yang secara bahasa berarti percampuran dua hal atau kepemilikan. ${ }^{40}$ Syirkah dibagi menjadi dua, yaitu syirkah amlak (kongsi harta) dan syirkah 'uqud (kongsi transaksi). Syirkah amlak merupakan kerjasama dalam hal kepemilikan antara dua pihak atau lebih terhadap suatu barang tanpa transaksi syirkah, sedangkan syirkah 'uqud merupakan suatu kerjasama antara dua pihak atau lebih dengan tujuan menjalin hubungan kerja dengan kesadaran dalam bentuk harta dan keuntungan. Syirkah hak milik ini dibagi menjadi dua, syirkah ikhtiyar (sukarela) yang dilakukan secara sengaja olah dua orang yang bersekutu seperti kedua orang yang mengadakan kongsi untuk membeli suatu barang, dan syirkah jabar (paksaan) yaitu telah melekat pada diri orang tersebut tanpa melakukannya, seperti dua orang yang mendapatkan warisan. ${ }^{41}$

Secara umum menurut para ulama fikih, syirkah 'uqud dibagi menjadi empat macam: ${ }^{42}$

1) Syirkah 'inan, yaitu persekutuan untuk memanfaatkan harta bersama sebagai modal untuk berdagang dan keuntungannya dibagi dua. Syirkah sejenis inilah yang paling popular dikalangan masyarakat, karena dalam syirkah ini tidak disyaratkan persamaan, baik dalam modal maupun dalam kerja.

2) Syirkah mufawadah, adalah persekutuan dua orang dalam suatu pekerjaan, dengan syarat keduanya sama dalam modal, pengelolaan harta dan agama, di mana masing-masing pihak menjadi penanggungjawab bagi yang lain.

3) Syirkah abdan atau syirkah a'mal, yaitu persekutuan dua orang dimana masing-masing memiliki pekerjaan.

4) Syirkah wujuh, yaitu persekutuan dua orang tanpa harus memiliki modal.

Hukum musyarakah adalah mubah dan boleh dilakukan antara sesama muslim atau antara orang kafir dzimmi. Rukun musyarakah ada tiga, yakni sighat (ijab dan kabul), pihak yang

\footnotetext{
${ }^{38}$ Ibid., 204.

${ }^{39}$ Yazid Afandi, Fiqh Muamalah, (Yogyakarta: Logung Pustaka, 2009), 120

${ }^{40}$ Muhammad Usman Syabir, al-mudkhal ila fiqh al-mu'amlat al-maliyah, (Pakistan: Darunnafaais, 2004),

${ }^{41}$ Ibid., 138.

${ }^{42}$ Wahbah al-Zuhaili, al-Figh al-Islam wa Adillatuhu, Jilid 4, (Damaskus: Dar al-Fikr, 1989),794
} 52. 
berakad, baik syarikah al-mal maupun syarikah al-abdan, dan usaha. ${ }^{43}$ Terdapat empat bagian yang harus dipenuhi syarat-syaratnya, yaitu: ${ }^{44}$

a. Sesuatu yang berhubungan dengan semua bentuk syirkah baik dengan harta maupun dengan yang lainnya. Dalam hal ini terdapat dua syarat, yaitu:

1) Apabila berupa benda, maka harus dapat diterima sebagai perwakilan.

2) Apabila berupa keuntungan, maka pembagian keuntungan harus jelas dan dapat diketahui dua pihak. Misalnya setengah, sepertiga dan yang lainnya.

b. Sesuatu yang berhubungan dengan syirkah mal (harta), dalam hal ini terdapat dua perkara yang harus dipenuhi yaitu:

1) Bahwa modal yang dijadikan objek akad Syirkah adalah dari alat pembayaran (nuqud), seperti junaih, riyal, dan rupiah.

2) Yang dijadikan modal (harta pokok) ada ketika akad syirkah dilakukan, baik jumlahnya sama atau berbeda.

c. Sesuatu yang bertalian dengan syirkah mufawadhah, bahwa dalam Syirkah mufawadhah disyaratkan:

1) Modal dalam syirkah mufawadhah harus sama

2) Bagi yang ber-Syirkah ahli untuk kafalah

d. Bagi yang dijadikan objek akad disyaratkan syirkah umum, yakni pada semua macam jual beli atau perdagangan

Akad yang dilakukan antara franchisor seblak coy dan franchisee dapat dikategorikan dalam syirkah 'uqud yaitu transaksi yang dilakukan dua orang atau lebih untuk menjalin persekutuan dengan sengaja dalam harta dan keuntungan. Dilihat dari syirkah 'uqud ini, kontrak franchise tersebut temasuk dalam kategori syirkah inan, yaitu persekutuan dua orang untuk memanfaatkan harta bersama sebagai modal untuk berdagang dan keuntungannya dibagi dua. Syirkah sejenis inilah yang paling popular dikalangan masyarakat, karena dalam syirkah ini tidak disyaratkan persamaan, baik dalam modal maupun dalam kerja (pengelola harta).

Modal bersama yang dimaksud adalah format bisnis, resep usaha seperti bumbu-bumbu dan fasilitas yang diberikan dari pihak Seblak Coy (franchisor) kepada pihak penerima waralaba (franchisee), serta modal pembayaran awal yang disebut initial fee seharga Rp. 20.000.000,yang diberikan dari franchisee kepada pihak Seblak Coy. Adapun keuntungan yang diperoleh franchisor adalah $10 \%$ dari hasil alokasi keuntungan bersih selama 30 hari atau satu bulan, sebagaimana ketentuan pada MoU di awal akad. Sedangkan keuntungan yang diperoleh franchisee adalah $15 \%$ dari keuntungan bersih selama 30 hari setelah dipotong alokasi dana untuk keperluan operasional usaha seperti biaya manajemen dan operasi, saving perusahaan, untuk maintenance alat, dan untuk insentif unit berupa THR (Tunjangan Hari Raya), Tunjangan Kesehatan, liburan karyawan dan Peningkatan kapasitas.

Ditinjau dari rukunnya, akad perjanjian yang dilakukan antara franchisor seblak coy dan franchisee, telah terpenuhi rukunnya dengan unsur sebagai berikut, adanya pihak yang berakad yaitu franchisor (pihak Seblak Coy) dan franchisee (penerima waralaba), adanya objek akad yaitu usaha yang dikelola pihak franchisee atas lisensi yang diberikan oleh franchisor, dan adanya sighat (ijab dan kabul) antara pihak penerima waralaba dan Seblak Coy yang dilakukan

${ }^{43}$ M.I. Yusanto dan M.K. Widjajakusuma, Menggagas Bisnis Islam, (Jakarta: Gema Insani Press. 2002), 133.

${ }^{44}$ Masjupri. Fiqh Muamalah, (Yogyakarta: Asnalitera, 2013), 170. 
berdasarkan perjanjian tertulis diantara keduanya. Selain rukunnya, juga akan dianalisis syaratsyarat musyarakah dalam kontrak waralaba di Seblak Coy.

Adapun syarat sah msyarakah yang berkaitan dengan kontrak waralaba di Seblak Coy mengenai sesuatu yang berhubungan dengan semua bentuk syirkah baik dengan harta maupun dengan yang lainnya. Hal ini harus terpenuhi oleh dua syarat, yaitu suatu objek berbentuk benda yang menjadi objek akad harus dapat berbentuk sebuah benda yang dapat diwakilan. Benda yang menjadi objek akad pada Seblak Coy ini dinyatakan dapat diterima sebagai perwakilan, karena Seblak Coy merupakan suatu bisnis kuliner dan dapat diketahui wujudnya yang dimiliki franchisor untuk dikelola oleh franchisee sebagai pihak yang mengikatkan diri untuk berserikat di bisnis Seblak Coy dalam bentuk kontrak waralaba.

Kemudian mengenai pembagian keuntungan, dalam kontrak waralaba Seblak Coy telah diatur dengan jelas menurut prosentase yang telah ditetapkan diawal akad dan dapat diketahui oleh dua pihak, yaitu dengan pembagian keuntungan 10\% untuk pihak I yaitu franchisor (Seblak Coy) dan 15\% untuk pihak II (franchisee), biaya operasional dan bahan jual sebesar 40\%, gaji cheff dan helper adalah sebesar $10 \%$, biaya manajemen dan operasi sebesar $10 \%$, saving perusahaan sebesar 5\%, alokasi untuk maintenance alat sebesar 5\%, dan alokasi untuk insentif unit sebesar 5\%.

Syarat lainnya yaitu sesuatu yang berhubungan dengan syirkah mal (harta), dalam hal ini terdapat dua perkara yang harus dipenuhi, yaitu modal yang dijadikan objek akad syirkah dalam kontrak waralaba di Seblak Coy adalah dari alat pembayaran yang sah yaitu uang dalam bentuk rupiah. Dan yang dijadikan modal (harta pokok) ada ketika akad syirkah dilakukan, yaitu satu format bisnis kuliner khas bandung dengan merek Seblak Coy yang di berikan oleh pihak I (franchisor), kemudian pihak II (franchisee) berkontribusi atas uang modal sejumlah Rp. 20.000.000,- sebagaimana telah ditentukan oleh pihak I dan tertera dalam bentuk kontrak baku yang dibuat oleh pihak I atas pertimbangan objek dan fasilitas yang didapat pihak II. Dana tersebut dialokasikan untuk peralatan memasak, pelatihan-pelatihan, fasilitas yang berkenaan dengan operasional usaha dan karyawan yang diberikan oleh pihak Seblak Coy kepada mitra, serta hak atas merek uasaha Seblak Coy. Selain itu mengenai syarat objek akad umum, yakni pada semua macam jual beli atau perdagangan. Objek kontrak waralaba di Seblak Coy merupakan objek perdagangan dengan bentuk suatu jenis usaha bersama yang modalnya berbeda jumlah dan bentuknya, juga keuntungan dibagi dua dengan proporsi yang telah disepakati.

Selanjutnya mengenai keabsahan akad ijarah yang terkandung di dalam kontrak waralaba dapat diketahui dengan cara memastikan terpenuhinya rukun dan syaratnya. Akad ijarah berasal dari kata al-ajru yang arti menurut bahasanya ialah al-iwad yang artinya ganti atau upah. Akad ijarah secara bahasa bermakna jual beli manfaat. Ijarah dapat diartikan sebagai hak untuk dapat memanfaatkan suatu objek akad dalam bentuk suatu barang atau jasa seseorang dengan membayar imbalan tertentu. ${ }^{45}$ Ijarah menurut imam syafi'i adalah akad atas suatu manfaat yang mengandung maksud yang tertentu, kebolehan dengan pengganti tertentu, dan boleh didermakan. ${ }^{46}$ Dalam ijarah terdapat rukun dan syarat sebagai berikut: ${ }^{47}$

a. Mu'jir dan musta'jir, disyaratkan baligh, berakal, cakap melakukan tasarruf (pengendalian harta) dan saling ridha.

\footnotetext{
${ }^{45}$ Wahbah al-Zuhaili, al-Fiqh al-Islam wa Adillatuhu, Jilid 4, .., 729.

${ }^{46}$ Kamil,Musa, Ahkam al-Mu'amalat, Cet. Ke-2, (Beirut: Muassasah al-Risalah, 1994), 295.

${ }^{47}$ Hendi Suhendi, Fiqh Muamalah, (Jakarta: PT Raja Grafindo Persada, 2010), 117.
} 
b. Sighat ijab kabul antara mu'jir dan musta'jir

c. Ujrah, disyaratkan diketahui jumlahnya oleh kedua belah pihak, baik dalam sewa menyewa maupun dalam upah mengupah.

d. Barang yang menjadi objek, hendaklah dapat dimanfaatkan, diserahkan kepada penyewa, manfaat dari benda bukan hal yang dilarang (diharamkan), dan disyaratkan kekal zat-nya hingga waktu yang ditentukan menurut perjanjian.

Sedangkan syarat sesuatu yang dikerjakan atas seorang pekerja yaitu: ${ }^{48}$

a. Perbuatan tersebut harus jelas batas waktunya dan jelas jenis pekerjaannya.

b. Pekerjaan yang menjadi objek ijarah yang berupa pekerjaan yang telah menjadi kewajiban pihak musta'jir (pekerja) sebelum berlangsungnya akad ijarah

c. Ujrah (ongkos sewa dan upah), disyaratkan harus berupa mal mutaqawwim dan dinyatakan secara jelas, harus berbeda dengan jenis objeknya.

d. Sighat, ijab kabul.

Ditinjau perspektif akad ijarah yang bermakna jual beli manfaat. Menurut Wahbah alZuhaili yang mendefinisikan ijarah sebagai hak untuk memanfaatkan barang atau jasa dengan membayar imbalan tertentu. ${ }^{49}$ Yang dapat dipahami bahwa akad ijarah tidak ada perubahan kepemilikan, tetapi hanya perpindahan hak guna saja. Dalam kontrak waralaba makanan Seblak Coy, terdapat unsur ijarah yang berbentuk pemberian lisensi kepada franchisee atau izin sewa merek selama 5 tahun dengan pembaharuan kontrak setiap satu tahun sekali. Pembaharuan kontrak ini bertujuan agar menyamaratakan perkembangan usaha, seperti penambahan ataupun perubahan menu, bahan baku atau bumbu-bumbu, dan perubahan manajemen pengelolaan. Jangka 5 tahun tersebut yang dimaksud sebagai jangka waktu sewa guna merek dan format bisnis Seblak Coy yang dimanfaatkan pihak franchisee.

Ditinjau dari rukun dan syarat ijarah, akad perjanjian yang dilakukan antara Seblak Coy dan franchisee telah terpenuhi unsurnya, yaitu adanya mu'jir yaitu pihak Seblak Coy (franchisor) dan musta'jir yaitu penerima waralaba (franchisee) dan telah terpenuhi syaratnya yaitu orang yang melakukan akad waralaba di Seblak Coy yaitu orang yang balig, berakal, cakap melakukan tasarruf (pengendalian harta) dan saling rela. Sighat ijab kabul antara mu'jir dan musta'jir, yaitu perjanjian ntara pihak penerima waralaba dan Seblak Coy yang dilakukan berdasarkan perjanjian tertulis. Ujrah yang dilakukan diawal akad dengan ketentuan jangka waktu sewa selama 5 tahun sejak melakukan kontrak. Kemudian Barang yang menjadi objek adalah sebuah format bisnis kuliner khas bandung yaitu seblak dan dapat dimanfaatkan, dapat diserahkan kepada penyewa, dan kekal zat-nya yaitu merek dagang dan format bisnisSeblak Coy hingga waktu yang ditentukan menurut perjanjian. Kuliner Seblak Coy juga bukan hal yang dilarang (diharamkan) karena kuliner Seblak Coy menggunakan bahan-bahan yang alami tanpa megandung unsur yang diharamkan dalam pembuatannya. ${ }^{50}$

Objek sewa sebagaimana pada akad ijarah tersebut yang harus dijaga dan dipergunakan sebagaimana mestinya karena objek merupakan sebuah hak cipta yang dilindungi oleh negara, serta memiliki hak dan kewajiban yang melekat bagi para pemiliknya. hak cipta (ibtikar) dapat diartikan secara etimologi sebagai awal sesuatu atau permulaannya. Ibtikar dalam fikih Islam adalah hak cipta kreasi yang dihasilkan seseorang untuk pertama kali. Di dalam dunia ilmu

\footnotetext{
${ }^{48}$ Masjupri. Fiqh Muamalah, ..., 213.

${ }^{49}$ Wahbah al-Zuhaili, al-Fiqh al-Islam wa Adillatuhu, Jilid 4, .., 729.

${ }^{50}$ Achmad Maulidiansyah, Pemilik Seblak Coy, Wawancara Pribadi, 21 November 2019.
} 
pengetahuan al-ibtikar disebut dengan hak cipta. Fathi al-Duraini sebagaimana dikutip Nasrun Haroen, menyatakan ibtikar adalah gambaran pemikiran yang dihasilkan seorang ilmuwan melalui kemampuan pemikiran dan analisisnya dan hasilnya merupakan penemuan atau kreasi pertama, yang belum dikemukakan ilmuwan sebelumnya. ${ }^{51}$

Kata haq al-ibtikar terdiri dari dua rangkaian kata yaitu kata "haq" dan "al-ibtikar". Pengertian " $h a q$ " adalah kekhususan yang dimiliki oleh seseorang atau sekelompok orang atas sesuatu. Dalam ruang lingkup haq al-ibtikar (hak cipta) maka lafadz haq adalah kewenangan atau kepemilikan atas suatu karya cipta yang baru diciptakan (al-ibtikar). ${ }^{52}$ Hak Cipta merupakan suatu hak eksklusif pencipta yang timbul secara otomatis berdasarkan prinsip deklaratif setelah suatu ciptaan diwujudkan dalam bentuk nyata. ${ }^{53}$ Pembuat karya adalah orang yang pertama membuatnya, sehingga dialah yang paling berhak terhadapnya, juga berhak mengubah karyanya, sebab karya itu di nisbatkan kepada dirinya. Karena statusnya, maka kalau karya tersebut dieksploitasi secara komersial, berarti sama dengan mengeksploitasi harta orang lain tanpa seizin pemilikinya. ${ }^{54}$

Hak cipta memiliki status yang sangat melekat dan tidak dapat dipisahkan dari HKI (Hak Kekayaan Intelektual) karena hak cipta adalah salah satu bagian dari HKI. Keberadaannya di lapangan hak cipta hidup berdampingan dengan HKI lainnya yaitu merek, paten, rahasia dagang, desain industri, dan desain tata letak sirkut. ${ }^{55}$ Pencipta mempunyai hak eksklusif untuk menikmati hasil ciptaannya atau dapat memberikan ijin kepada orang lain untuk menggunakan ciptaannya. dalam hak cipta terkandung hak ekonomi (haq al-iqtisadi) dan hak moral (haq aladabi), maka setiap orang yang memiliki karya dari hasil buatannya sendiri berhak atas materi dari karya ciptanya tersebut. ${ }^{56}$ Hak cipta adalah sesuatu hubungan khusus yang diakui syarak antara pencipta dan abstraksi pemikiran hasil kekuatan intelektualnya. Dengan hubungan khusus tersebut, pencipta atau pemegang hak cipta memiliki kewenangan untuk mempergunakan abstraksi pemikiran tersebut secara bebas dengan tetap mentaati ketentuan syarak. ${ }^{57}$

Jika hak ini tidak dilindungi tentu akan mengakibatkan berbagai kerusakan di tengah masyarakat, seperti enggannya para pembuat karya cipta untuk menciptakan sebuah karya yang menjadi keahliannya, tidak berkembangnya tekhnologi dan ilmu pengetahuan karena tidak ada lagi orang-orang yang mau menciptakan berbagai penemuan dari hasil-hasil penelitiannya. Secara de facto hak cipta telah menjadi bagian dari kehidupan umat manusia sehari-hari, sementara tidak ada nash sharih yang membahas tentang hal ini, dan mereka tidak merasa keberatan dengan hal ini, sehingga 'urf dijadikan sandaran hukumnya perlindungan terhadap HKI merupakan suatu kemaslahatan karena ini suatu bentuk apresiasi dan penghargaan serta tindakan preventif kepada pencipta karya agar tidak terjadi kedzaliman terhadap pemiliknya, sedangkan

\footnotetext{
${ }^{51}$ Nasrun Haroen. 2002. Fiqh Muamalah. Jakarta: Gaya Media Pratama, 237.

${ }^{52}$ Munawwir, Kamus al-Munawwir Arab-Indonesia Terlengkap, (Surabaya: Pustaka Progressif, 1997), 101.

${ }_{53}^{53}$ Undang-Undang RI, Nomor 28 Tahun 2014 tentang Hak Cipta, Pasal 1.

${ }^{54}$ Syaikh Ziyad Ghazal, Buku Pintar Bisnis Syar'i, ..., 188.

${ }^{55}$ Gatot Supramono, Hak Cipta dan Aspek-Aspek Hukumnya, (Jakarta: Rineka Cipta, 2010), 45.

${ }^{56}$ Lutfi Ulinnuha, "Penggunaan Hak Cipta Sebagai Objek Jaminan Fidusia," Journal of Private and Commercial Law Vol. 1, No. 1 (2018), 87.

${ }^{57}$ Agus Suryana, "Hak Cipta Perspektif Hukum Islam" Al-Maslahah Jurnal Hukum dan Pranata Sosial Islam, Vol. 3, No. 19 (2015), 252.
} 
kemaslahatan yang diambil adalah adanya hak untuk menikmati sebuah ciptaan bagi pemiliknya baik dari segi moral maupun material. ${ }^{58}$

Menurut perspektif ibtikar waralaba makanan Seblak Coy merupakan salah satu gambaran pemikiran yang dihasilkan seseorang melalui kemampuan pemikiran dan analisisnya dan hasilnya merupakan penemuan atau kreasi pertama. Kang Imo adalah orang yang pertama membuat usaha kuliner Seblak Coy, sehingga dialah yang paling berhak terhadapnya, juga berhak mengubah karyanya, sebab dia adalah pembuatnya, dan karya itu dinisbatkan kepada dirinya. Jadi tenaga yang dicurahkan kang Imo untuk mengahasilkan karya kreatif merupakan harta dan harus dilindungi dan berhak untuk mendapatkan materi dari karya ciptanya tersebut.

Seblak Coy juga merupakan bisnis waralaba yang telah dilindungi oleh negara dan termasuk dalam kategori Hak Kekayaan Intelektual, karena esensi bisnis waralaba adalah hak merek dagang dari produk atau jasa yang telah memperoleh paten dan hak cipta. Seblak Coy adalah pemilik HKI (Hak Kekayaan Intelektual) dan juga produsen barang, karena itu pihak Seblak Coy melakukan kontrol yang sangat ketat kepada franchisee yang bertujuan untuk melindungi HKI secara seksama. Dengan demikian si franchisee/licensee harus mengikuti sistem yang ada sesuai ketentuan yang telah ditetapkan oleh pihak Seblak Coy. Pihak Seblak Coy dapat mengontrol unsur-unsur transaksi seperti tempat pendirian bisnis, gerai atau materi iklan, apa yang dapat digunakan franchisee sesuai dengan MoU pada awal kesepakatan dilakukan. Pihak Seblak Coy juga memberi pelatihan kepada franchisee dan karyawannya agar format bisnis disemua operasional dari segi intern dan ekstern memiliki kesamaan.

Karena status Seblak Coy tersebut, kalau karya tersebut seperti merek atau hal yang berkaitan dengan Seblak Coy dieksploitasi secara komersial, maka negara berhak melakukan intervensi dalam menanganinya untuk mengembalikan harta benda kepada pemiliknya yang sah. Bahkan lebih jauh dari itu, negara berhak menyita kepemilikan illegal tersebut, baik itu berupa harta bergerak maupun harta benda tidak bergerak. Tindakan tersebut berarti sama dengan mengeksploitasi harta orang lain tanpa seizin pemilikinya. Dan apabila pihak franchisee tidak menjaga dengan baik lisensi tersebut serta melanggar Standar Operasional Prosedur (SOP) maka akan diberi teguran dan pihak Seblak Coy berhak mencabut merek tersebut dan memutuskan kemitraan. Apabila terjadi perselisihan maka akan diselesaikan secara Musyawarah atau melalui Pengadilan Negeri apabila perselisihan tidk dapat diselesaikan secara musyawarah.

Berdasarkan penjabaran tersebut, maka dapat diketahui bahwa kontrak waralaba (franchise) di Seblak Coy termasuk dalam kategori multi akad, karena akad pertama (musyarakah) tergantung pada akad kedua (ijarah) dan ketiga (al-ibtikar). Juga terdapat unsurunsur yang merupakan karakteristik multi akad pada kontrak waralaba di Seblak Coy, karena pelaku akad atau seluruh pihak akad sama yaitu dalam akad musyarakah Seblak Coy dan franchisee sebagai pihak yang berserikat dalam suatu hubungan kerja, dalam akad ijarah Seblak Coy (franchisor) dan mitra (franchisee) sebagai mu'jir dan musta'jir, kemudian dalam ibtikar Seblak Coy sebagai pemberi lisensi dan mitra waralaba sebagai penerima lisensi atas format bisnis dan juga merek yang dimiliki pihak Seblak Coy. Objek akad pada kontrak waralaba di Seblak Coy sama, yaitu format bisnis dan merek yang menjadi objek akad dalam musyarakah, ijarah dan ibtikar.

Memiliki pengaruh akad yang sama, yaitu berpengaruh menghasilkan suatu keuntungan bagi kedua belah pihak yang telah dibagi menurut proporsi masing-masing. Adanya pengaruh

${ }^{58}$ Ibid., 253. 
dari satu akad terhadap akad yang lainnya, yang saling berketerkaitan dan tidak dapat dipisahkan demi terpenuhinya sebuah kontrak waralaba (franchise), karena dalam kontrak waralaba di Seblak Coy ini yang menjadi objek adalah format bisnis dan juga mencakup lisensi atas merek, bukan hanya sekedar merek saja ataupun persekutuan modal saja. Kemudian ada ta'alluq (saling memahami) antara akad-akad tersebut, yaitu akad pertama (musyarakah) memahamkan akan akad selanjutnya dan akad kedua (ijarah) memperjelas akad pertama, begitu juga ibtikar menjadi penting dalam kontrak waralaba di Seblak Coy yang tidak dapat dipisahkan dari akad musyarakah dan ijarah dalam pelaksanaan kontrakya.

Unsur multi akad lainnya yang harus terpenuhi yaitu mengenai penggabungan akadnya. Akad-akad yang terimplementasi pada kontrak waralaba Seblak Coy tidak termasuk akad yang dilarang dalam nash untuk digabungkan, karena akad-akad yang terkandung dalam waralaba Seblak Coy saling membutuhkan keberadaan akad lainnya, juga bukan akad yang dilarang seperti penggabungan jual beli dan pinjaman. Kontrak waralaba Seblak Coy tidak termasuk dalam hilal ribawiyah karena dapat diketahui spesifikasiya, ada pembagian modal dan keuntungan sesuai proporsi yang telah disepakati oleh para pihak. Penggabungan akadnya tidak menyebabkan riba seperti menjual sesuatu dengan syarat pembeli meminjamkan sesuatu kepada penjual, waralaba Seblak Coy tidak memiliki unsur seperti itu dalam kontraknya, karena akadakad yang terkandung didalam kontraknya adalah akad musyarakah, ijarah dan ibtikar yang sudah jelas ketentuan dan syaratnya.

Praktik kontrak waralaba Seblak Coy bukan termasuk hukumnya berentengan seperti antara hibah dan jual beli, tetapi akad yang digabungkan adalah akad kerjasama (musyarakah) yang didalam salah satu rukun kerjasama tersebut harus terjadi akad sewa (ijarah) yaitu sewa atas merek selama 5 tahun, karena merek Seblak Coy telah terdaftar sebagai bisnis waralaba. Maka dari itu terdapat hak melekat pada merek yang menjadi objek sewa yaitu Hak Kekayaan Intelaktual yang harus dilindungi oleh pihak-pihak waralaba, didalam hukum Islam hak cipta disebut ibtikar. Multi akad pada kontrak waralaba Seblak Coy termasuk dalam multi akad yang tidak menggunakan rangkaian berurutan (akad pertama dilengkapi dengan akad kedua dan seterusnya). Terbukti bahwa bisnis waralaba kuliner Seblak Coy dilakukan dengan satu akad saja, yaitu akad waralaba tetapi didalamnya terkandung akad musyarakah, ijarah, ibtikar yang satu sama lainnya harus saling melengkapi.

\section{Penutup}

1. Waralaba (franchise) adalah sebuah perjanjian mengenai metode pendistribusian barang dan jasa kepada konsumen. Pemberi waralaba memberikan lisensinya kepada penerima waralaba dalam kurun waktu tertentu untuk melakukan usaha dibawah nama identitas pemberi waralaba. Ada dua pihak dalam perjanjian waralaba yaitu, pemberi waralaba (franchisor) dan penerima waralaba (franchisee). Objek kontrak waralaba adalah Hak Kekayaan Intelektual (HKI) yang diwujudkan dalam bentuk merek dan produk dagang ataupun format bisnis. Seblak coy adalah salah satu bisnis kuliner waralaba dengan masa perjanjian waralaba pada Seblak Coy selama 5 tahun dan dapat diperpanjang. Dalam jangka 5 tahun ini, selalu dilakukan pembaharuan kontrak di setiap satu tahun sekali. Untuk menjadi mitra, calon mitra harus melakukan prosedur yang telah ditetapkan oleh pihak Seblak Coy seperti menyiapkan lokasi dan tempat, kesepakatan MoU (Memorandum of Understanding), serta melakukan pembayaran initial fee, Kemudian franchisee akan mendapatkan produk yaitu format bisnis dan merek serta fasilitas-fasilitas yang menunjang usaha. Juga Hak dan kewajiban para pihak harus dipatuhi sebagaimana tercantum pada MoU di awal akad. 
2. Kontrak waralaba yang dipraktikkan di waralaba makanan Seblak Coy termasuk dalam multi akad yang diperbolehkan dalam hukum Islam terbukti bahwa akad kerjasama yang terjadi pada Seblak Coy dalam hukum Islam disebut sebagai akad musyarakah. Selain akad tersebut, juga telah terjadi akad sewa merek usaha yang dalam hukum Islam disebut akad ijarah dikarenakan merek usaha yang digunakan penerima waralaba adalah milik franchisor dan telah dipatenkan untuk dilindungi oleh negara. Perlindungan nama baik perusahaan atau hak ciptanya harus dijaga dengan baik oleh penerima waralaba dengan mengikuti ketentuan dan prosedur yang telah disepakati, dalam hukum Islam hak cipta disebut sebagai ibtikar. Dari transaksi tersebut terlihat bahwa adanya ketergantungan antara satu akad dengan akad yang lain, juga karena seluruh pihak akad dan objek akad dalam ketiga akad tersebut sama. Pihak penyewa dan yang menyewakan adalah sama, begitu pula pemberi lisensi dan penerima lisensi adalah sama, maka transaksi yang dipraktikkan oleh pihak-pihak tersebut termasuk dalam kategori multi akad. Multi akad pada kontrak waralaba Seblak Coy termasuk dalam multi akad yang tidak menggunakan rangkaian berurutan karena pada bisnis waralaba kuliner Seblak Coy dilakukan dengan satu kontrak saja namun harus saling berkaitan antara satu akad dan akad lainnya, yaitu akad waralaba tetapi didalamnya terkandung akad musyarakah, ijarah, ibtikar (hak cipta).

\section{Buku}

\section{DAFTAR PUSTAKA}

Afandi, Yazid, 2009, Fiqh Muamalah, Logung Pustaka, Yogyakarta. Antonio, Muhammad Syafi'i, 2001, Bank Syariah Dari Teori Ke Praktik, Gema Insani, Jakarta. Al'Asqalani, Ibnu Hajar, 2006, Bulughul Maram, terj. A. Hasan, CV Penerbit Diponegoro, Bandung.

Burhanuddin, 2009, Hukum Kontrak Syariah, BPFE, Yogyakarta.

Ghazal, Syaikh Ziyad, 2011, Buku Pintar Bisnis Syar'i, Al-Azhar press Bogor.

Haroen, Nasrun, 2002. Fiqh Muamalah. Gaya Media Pratama, Jakarta.

Masjupri. 2013, Fiqh Muamalah, Asnalitera, Yogyakarta.

Mubarok, Jaih, 2002, Sejarah dan Kaidah Asasi,Raja Grafindo Persada, Jakarta.

Musa, Kamil, 1994, Ahkam al-Mu'amalat, Cet. Ke-2, Muassasah al-Risalah, Beirut-

Suhendi, Hendi, 2010, Fiqh Muamalah, PT Raja Grafindo Persada, Jakarta.

Nickels, William G, 2009, Pengantar Bisnis, Salemba Empat, Jakarta.

Ridwan, Muhammad, 2007, Konstruksi Bank Syariah Indonesia, Pustaka SM, Yogyakarta.

Sahroni, Oni dan M. Hasanuddin, 2016, Fikih Muamalah: Dinamika Teori Akad dan Implementasinya Dalam Ekonomi Syariah, Raja Grafindo Persada, Jakarta.

Silondae, Arus Akbar dan Andi Fariana, 2013, Aspek Hukum dalam Ekonomi dan Bisnis, Mitra Wacana Media, Jakarta.

Sugiyono, 2014, Metode Penelitian Kuantitatif Kualitatif dan $R \& D$, Alfabeta, Bandung. Supramono, Gatot, 2010 Hak Cipta dan Aspek-Aspek Hukumnya, Rineka Cipta, Jakarta.

Syabir, Muhammad Usman, 2004, al-mudkhal ila fiqh al-mu'a>mla>t al-ma>liyah, Darunnafaais, Pakistan.

Yusanto, M.I. dan M.K. Widjajakusuma, 2002, Menggagas Bisnis Islam, Gema Insani Press. Jakarta. 
Zahrah, Muhammad Abu, 1996, al-Milkiyyah wa Nazariyyatu al-'Aqd, Dar al-Fikr al-Arabi, Kairo.

Zaidani, Abdul Karim, 1996, al-Mudkhal al-Syariah al-Islamiyyah, Muassasah al-Risalah, Beirut.

al-Zuhaili, Wahbah, 1989, al-Fiqh al-Isla>m wa Adillatuhu, Jilid 4, Dar al-Fikr, Damaskus.

Artikel Jurnal

Aidi, Zil, and Hasna Farida. "Perlindungan Hukum Para Pihak Dalam Perjanjian Waralaba Makanan.” JCH (Jurnal Cendekia Hukum), Vol. 4, No. 2, Maret 2019.

Aryanti, Yosi. "Multi Akad (Al-Uqud Al-Murakkabah) Di Perbankan Syariah Perspektif Fiqh Muamalah." JURIS (Jurnal Ilmiah Syariah) Vol. 15, No. 2, Desember 2016.

Harun, Harun. "Multi Akad Dalam Tataran Fiqh.” Jurnal Suhuf, Vol. 30, No. 2, November 2018.

Idrus, Norman Syahdar. "Aspek Hukum Perjanjian Waralaba (Franchise) Dalam Perspektif Hukum Perdata Dan Hukum Islam.” Jurnal Yuridis, Vol. 4, No. 1, Juni 2017.

Fahmiyah, Inas dan Moh. Idil Ghufron "Konsep Waralaba Perspektif Ekonomi Islam", Vol. 3, No. 1, Januari 2019.

Linda Firdawati. "Perjanjian Waralaba Menurut Hukum Islam.” Asas 3, no. v (2011): Vol.3, No.1, November 2017.

Maulana, Hasanudin. "Multi Akad Dalam Transaksi Syariah Kontemporer Pada Lembaga Keuangan Syariah Di Indonesia." Al-Iqtishad: Journal of Islamic Economics, Vol. 3, No. 1, Januari 2011.

Santoso, Lukman, "Urgensi Tanda Tangan dan Materai Dalam Memberikan Kepastian Hukum Terhadap Kontrak Waralaba (franchise)" Syariah: Jurnal Hukumdan Pemikiran, Vol. 16, No. 2, Desember 2016.

Suryana, Agus, "Hak Cipta Perspektif Hukum Islam" Al-Maslahah Jurnal Hukum dan Pranata Sosial Islam, Vol. 3, No. 19, 2015.

Susamto, Burhanuddin. "Tingkat Penggunaan Multi Akad Dalam Fatwa Dewan Syari'Ah Nasional-Majelis Ulama Indonesia (Dsn-Mui)." Al-Ihkam: Jurnal Hukum \& Pranata Sosial Vol. 11, No. 1, Juni 2016.

Ulinnuha, Lutfi. "Penggunaan Hak Cipta Sebagai Objek Jaminan Fidusia." Journal of Private and Commercial Law, Vol. 1, No. 1, November 2018.

Internet dan lain-lain

Alodokter, "Kontroversi Umami dari MSG", https://www.alodokter.com/kontroversi-umamidari-msg, diakses pada 9 Agustus 2020.

Kamus Besar Bahasa Indonesia, "Multi", https://kbbi.web.id/multi, diakses pada 8 Januari 2020.

Maulidiansyah, Achmad, Pemilik Seblak Coy, Wawancara Pribadi. 2019.

Munawwir, 1997, Kamus al-Munawwir Arab-Indonesia Terlengkap, Pustaka Progressif, Surabaya.

Peraturan Perundang-undangan

Undang-Undang Nomor 42 Tahun 2007 Tentang Waralaba.

Undang-Undang Nomor 28 Tahun 2014 Tentang Hak Cipta. 